\title{
Stopnie wodne na Odrze i ich potencjalny wpływ na wody podziemne
}

\author{
Grzegorz Firlit ${ }^{1}$, Jacek Szczepiński ${ }^{1}$
}

\begin{abstract}
The Odra barrages and their potential influence on groundwater. Prz. Geol., 68: 287-291; doi: 10.7306./2020.17
A b s tra c t. Hydraulic constructions have a significant impact on the surface water regime, and on the soil and groundwater conditions of the entire adjacent valley. Above the water barrages, surface water is being accumulated and the river changes its character to infiltrating. Below the barrages, there is deep erosion of the riverbed, the surface water level and the groundwater drainage base decrease, which results in the lowering of the groundwater level in the adjacent river valley. The examples of such phenomena are barrages on the Odra River downstream Wrocław. After the construction of barrages in Rędzin, Brzeg Dolny and, recently, in Malczyce, a process of intensive deep erosion of the Odra riverbed is observed, currently along the section from Malczyce to Ścinawa. It ranges from $0.8 \mathrm{~m}$ in Ścinawa to $2 \mathrm{~m}$ in Malczyce. This results in a lowering of the groundwater level of the first aquifer on the discussed section of the Odra Valley. This phenomenon has a particularly negative impact on the Eegi Odrzańskie area conditions that are closely dependent on the groundwater level. The greatest damage occurs in oak-elm-ash riparian forests and concerns the oldest oaks. Lęi Odrzańskie is a valuable ecosystem with numerous protected species that have been legally protected under the Natura 2000 network and national forms of nature protection and protected landscape areas. The designed barrages in Lubiaż and Ścinawa will stop the progressive deep erosion of the Odra riverbed. They will contribute to raising and stabilizing the groundwater level in the Odra Valley, which will partly return to a nearly natural level.
\end{abstract}

Keywords: barrages, Odra River, groundwater-surface water interaction

Przez wiele setek lat Odra była rzeką, która płynęła swobodnie, tworząc szeroką dolinę z licznymi meandrami, odnogami i kanałami. Nad jej brzegami rozwijało się osadnictwo, rolnictwo, a następnie także przemysł. Od najdawniejszych czasów Odra pełniła również funkcję ważnego szlaku transportowego. Aby usprawnić żeglugę rzeczną oraz zabezpieczyć dolinę przed powodziami wykonywano różne prace hydrotechniczne - najdawniejsze są datowane na XIII w. i dotyczyły regulacji koryta Odry, miały one jednak niewielki zasięg. Dopiero w wieku XIX, wraz z rozwojem górnictwa węgla kamiennego na Górnym Śląsku i rosnącą potrzeba jego transportu, przystapiono do kompleksowej regulacji koryta Odry za pomocą budowli poprzecznych, tj. ostróg. Zakładana głębokość żeglowna w pasie wodnym miała wynosić $1,0 \mathrm{~m}$. Okazało się jednak, że w latach suchych głębokość ta spadała na niektórych odcinkach do 0,7 m, uniemożliwiając tym samym żeglugę. Pod koniec XIX w. inżynierowie niemieccy podjęli decyzję o skanalizowaniu Odry na odcinku od Koźla do Wrocławia, gdzie wybudowano 22 stopnie wodne oraz Wrocławski Węzeł Wodny. Ostatnią budową hydrotechniczną, którą oddano do użytku, był stopień wodny w Rędzinie (1923 r.). Poniżej tego najniższego stopnia wodnego w kaskadzie, doszło do erozji liniowej koryta Odry (Nowicka i in., 2015).

$\mathrm{Z}$ tego względu zdecydowano o budowie kolejnego stopnia wodnego w Brzegu Dolnym, który powstał w $1958 \mathrm{r}$. Nie rozwiązał on jednak problemu erozji dna, jedynie przesunął ją na kolejny odcinek, przyczyniając się jednocześnie do jeszcze intensywniejszej erozji. Zasięg erozji w $1993 \mathrm{r}$. wyniósł 50 km, a w roku 2007 sięgnął 65 km, czyli do miejscowości Ścinawa. Aby powstrzymać to zjawisko w 1974 r. wydano decyzję lokalizacyjną dla kolejnego stopnia wodnego Malczyce (zlokalizowanego w Rzeczycy), którego budowa rozpoczęła się jednak dopiero w roku 1997 i trwała ponad 20 lat.

W dniu 14 czerwca 2016 r. Rada Ministrów przyjęła uchwałę w sprawie Założeń do planów rozwoju śródla- dowych dróg wodnych w Polsce na lata 2016-2020 z perspektywa do roku 2030 (Uchwała, 2016). Jej podstawą była Ekspertyza w zakresie rozwoju śródladowych dróg wodnych $w$ Polsce na lata 2016-2020 z perspektywa do roku 2030 opracowana przez Ministerstwo Gospodarki Morskiej i Żeglugi Śródlądowej. Ekspertyza ta zakłada budowę na odcinku Odry swobodnie płynącej (od Brzegu Dolnego - 281,6 km do ujścia Warty w miejscowości Kostrzyn - 617,6 km) 15 stopni wodnych w miejscowościach: Malczyce (stopień wodny zrealizowany), Lubiąż, Ścinawa, Rajczyn, Chełm, Wietszyce, Głogów, Żukowice, Bytom Odrzański, Nowa Sól, Młynkowo, Klenica, Pomorsko, Krosno Odrzańskie i Krzesin. Planowane stopnie wodne mają na celu podniesienie warunków żeglugowych na Odrze do klasy Va, ale również zahamowanie erozji dennej, przywrócenie naturalnego poziomu wód gruntowych i produkcję czystej energii elektrycznej. Obecnie na etapie projektowym są 2 stopnie wodne - Lubiąż i Ścinawa, których inwestorem jest Państwowe Gospodarstwo Wodne Wody Polskie (PGW WP), Regionalny Zarząd Gospodarki Wodnej (RZGW) we Wrocławiu.

\section{OBSZAR BADAŃ}

Największe zmiany w korycie Odry na skutek erozji wgłębnej zachodzą na odcinku od stopnia wodnego Malczyce w Rzeczycy do Ścinawy, tj. na 300,4-332,0 km rzeki. Na odcinku od Brzegu Dolnego przez Rzeczycę Odra płynie w kierunku SW, po czym na wysokości Malczyc szerokim łukiem zmienia kierunek na N (ryc. 1). Od zachodu omija wzgórza morenowe na wysokości Lubiąża, łączy się z Kaczawą (lewym dopływem Odry), a następnie przecina Wał Trzebnicki, na odcinku którego Odra ma przełomowy charakter. Szerokość doliny Odry na tym odcinku waha się od 1,5 do 6,0 km. Po obu stronach rzeki występują liczne starorzecza, które są cennymi siedliskami dla fauny i flory. Dno doliny Odry, tarasy zalewowe i niższe tarasy

\footnotetext{
${ }^{1}$ „Poltegor-Instytut” Instytut Górnictwa Odkrywkowego, ul. Parkowa 25 9, 51-616 Wrocław; grzegorz.firlit@igo.wroc.pl
} 


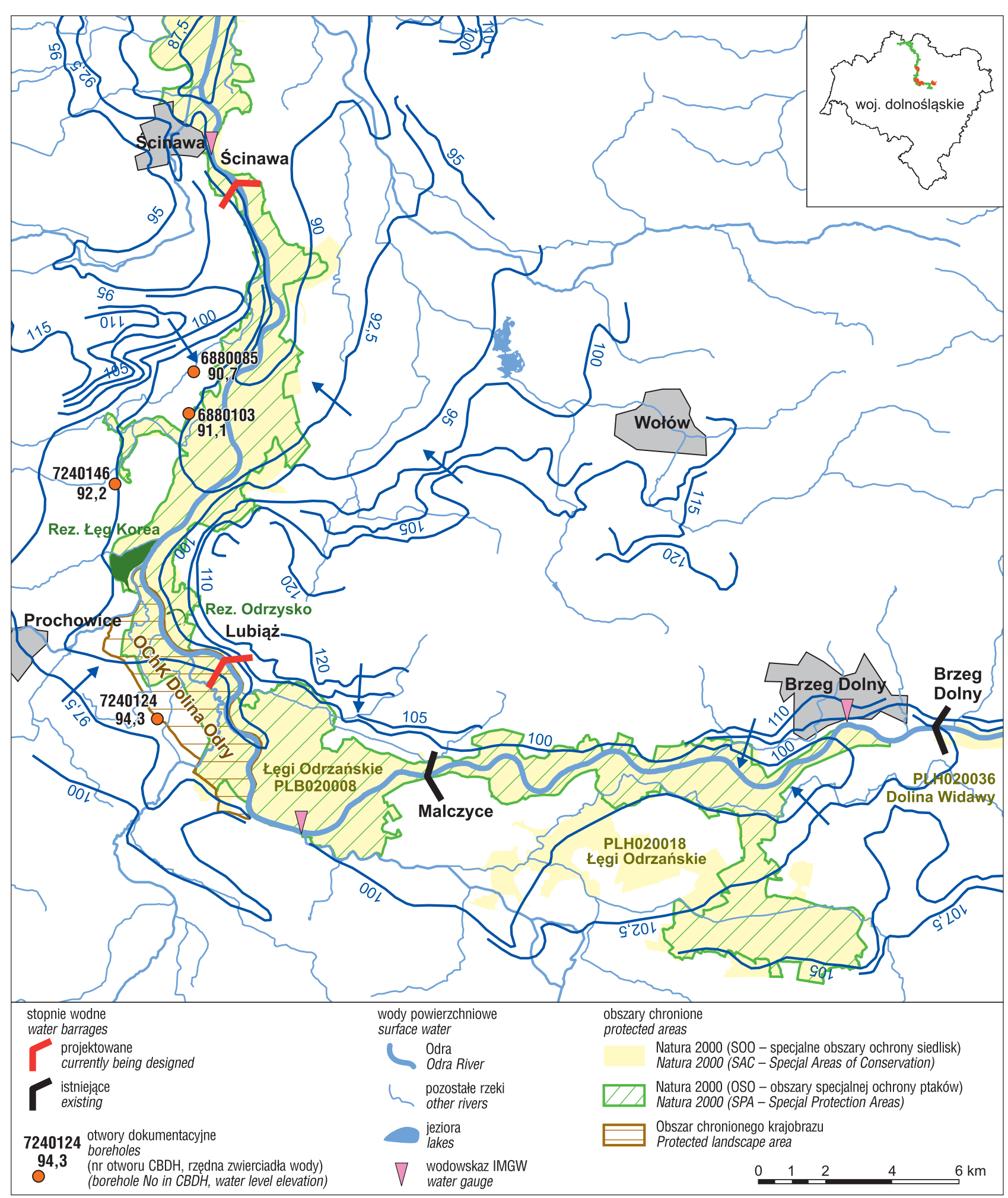

Ryc. 1. Wstępna lokalizacja stopni wodnych Malczyce i Lubiąż na rzece Odrze

Fig. 1. Preliminary location of the Malczyce and Lubiąż barrages on the Odra River

zalewowe są porośnięte lasami liściastymi (łęgi i grądy), wyższe partie doliny są wykorzystywane rolniczo, pod uprawy. Duże znaczenie na tym obszarze mają również łąki.

\section{WARUNKI GEOLOGICZNE I HYDROGEOLOGICZNE DOLINY ODRY}

Piętro wodonośne w dolinie Odry jest związane z przepuszczalnymi osadami plejstoceńskimi zdeponowanymi w Pradolinie Wrocławskiej w trakcie interglacjału mazo- wieckiego i eemskiego. Na nich zalegają osady holoceńskie, które tworzą współczesną dolinę Odry w postaci tarasów nadzalewowych, tarasów zalewowych niższych i wyższych oraz dno doliny. Budują je piaski i żwiry rzeczne, które osiągają miąższość średnio 10-20 m, lokalnie do $40 \mathrm{~m}$ (Szałajdewicz, 1980; Michalska, 1981). Zwierciadło wody w dolinie Odry ma swobodny charakter i zalega na głębokości ok. $2 \mathrm{~m}$, lokalnie do $5 \mathrm{~m}$. Omawiane piętro wodonośne stanowi główny użytkowy poziom wodonośny (Malinowska-Pisz, 1997). Korzystne parametry hydrogeologiczne 
warstwy wodonośnej, tj. średni współczynnik filtracji $43,8 \mathrm{~m} / 24 \mathrm{~h}$, średnia przewodność warstw wodonośnych $-415,0 \mathrm{~m}^{2} / 24 \mathrm{~h}$ oraz wydajności potencjalne studni wierconych osiagające $\mathrm{w}$ centralnej części doliny wartości z przedziału $70-120 \mathrm{~m}^{3} / \mathrm{h}$ czynią tą warstwę głównym źródłem zaopatrzenia ludności i przemysłu w wodę na omawianym obszarze. Odpływ wód podziemnych odbywa się w kierunku rzeki Odry, która dla całej doliny stanowi bazę drenażu. Zasilanie czwartorzędowego, dolinnego piętra wodonośnego odbywa się poprzez bezpośrednią infiltrację wód opadowych do warstwy wodonośnej (Gurwin, 2011). Wielkość zasilania poziomu wodonośnego doliny Odry można utożsamiać z wielkością opadów na tym obszarze (ryc. 2).

Pomiarów wielkości opadów na wymienionych stacjach IMGW zaprzestano w 2015 r. Średnia roczna suma opadów z lat 1971-2014 na stacji w Brzegu Dolnym wynosi $585,0 \mathrm{~mm}$, a na stacji w Malczycach 600,9 mm. Analizując linię trendu opadów z latach 1971-2014, w Malczycach nie widać wyraźnej tendencji w zmianie sumy opadów rocznych. Linia trendu ma przebieg niemal poziomy i opisuje ją równanie: $\mathrm{y}=0,029 \mathrm{x}+600,22$.

Znaczna część doliny Odry jest objęta ochroną w ramach Europejskiej Sieci Ekologicznej Natura 2000. W dolinie Odry na odcinku od Brzegu Dolnego do Głogowa występują dwa rodzaje obszarów o wspólnej nazwie Łęgów Odrzańskich, tj. Obszar Specjalnej Ochrony Ptaków (OSO) - (PLB020008) i Specjalny Obszar Ochrony Siedlisk (SOO) - (PLH020018). Oś obszarów chronionych tworzy Odra. Przedmiotem ochrony na terenie Łęgów Odrzańskich jest 11 siedlisk przyrodniczych, m.in.: starorzecza i zbiorniki eutroficzne, rzeki ze zbiorowiskami włosieniczników, zalewane muliste brzegi rzek, murawy kserotermiczne, murawy ciepłolubne, zmiennowilgotne łąki trzęślicowe, ziołorośla górskie i nadrzeczne, łąki selenicowe, grądy środkowoeuropejskie, łęgi wierzbowe, topolowe, olszowe i jesionowe, olsy źródliskowe, łęgowe lasy dębowo-wiązowo-jesionowe oraz kwaśne dąbrowy. Ochroną są objęte 22 gatunki fauny: ssaki - 4 gatunki nietoperzy, bóbr europejski i wydra, płazy - traszka grzebieniasta i kumak nizinny, 5 gatunków ryb, 9 gatunków bezkręgowców, wśród nich motyle i chrząszcze (Ruszlewicz, 2015). Dla większości siedlisk chronionych i zamieszkujących je zwierząt bardzo duży wpływ na ich funkcjonowanie i rozwój ma poziom wód powierzchniowych i podziemnych. Obszar obejmuje również inne formy ochrony przyrody rezerwaty przyrody: Łęg Korea, Odrzysko, obszar chronionego krajobrazu Dolina Odry (ryc. 1).

\section{WPLYW STOPNI WODNYCH NA POZIOM WÓD PODZIEMNYCH}

Stopnie wodne jako budowle hydrotechniczne zaburzają dynamikę warunków wodnych - powyżej nich dochodzi do piętrzenia wód powierzchniowych, a rzeka zmienia charakter na zasilający. Poniżej stopnia wodnego rzeka ma charakter drenujący wody podziemne. W przypadku najniższego stopnia wodnego w kaskadzie dochodzi dodatkowo do erozji liniowej koryta rzeki, a co za tym idzie stałego obniżania się bazy drenażu wód podziemnych. Erozja liniowa poniżej stopnia wodnego w Brzegu Dolnym objęła odcinek rzeki o długości ok. $65 \mathrm{~km}$, tj. do Ścinawy. Średni poziom dna Odry obniża się o 4-8 cm rocznie, a objętość wyerodowanego rumowiska szacuje się rocznie na 100 tys. $\mathrm{m}^{3}$ (Parzonka i in., 2010). Tempo erozji zmniejszyło się w ostatnich latach na skutek wymycia drobnej frakcji z koryta rzeki, czyli powstania procesu tzw. obrukowania dna koryta. Według badań Parzonki i in. (2010) dno Odry na odcinku między Malczycami $(300 \mathrm{~km})$, a Ścinawa (335 km) obniżyło się średnio o 2,0 m w Malczycach i 0,8 m w Ścinawie.

Obniżenie poziomu wód powierzchniowych jako bazy drenażu dla wód podziemnych spowodowało obniżenie pierwszego poziomu wodonośnego wód podziemnych w całej przylegającej dolinie. Potwierdzają to badania prowadzone m.in. przez Nowickąi in. (2015). Autorzy wykazują związek obniżania się zwierciadła wód gruntowych ze stanami wody w Odrze na przestrzeni 42 lat w dolinie Odry, poniżej stopnia wodnego w Brzegu Dolnym. Tendencja obniżania się zwierciadła wody podziemnej wyniosła w latach 1998-2012 średnio 2,35 cm/rok w dolinie położonej najbliżej koryta rzeki i malała w miarę odsuwania się od koryta. Obniżanie się zwierciadła wody podziemnej

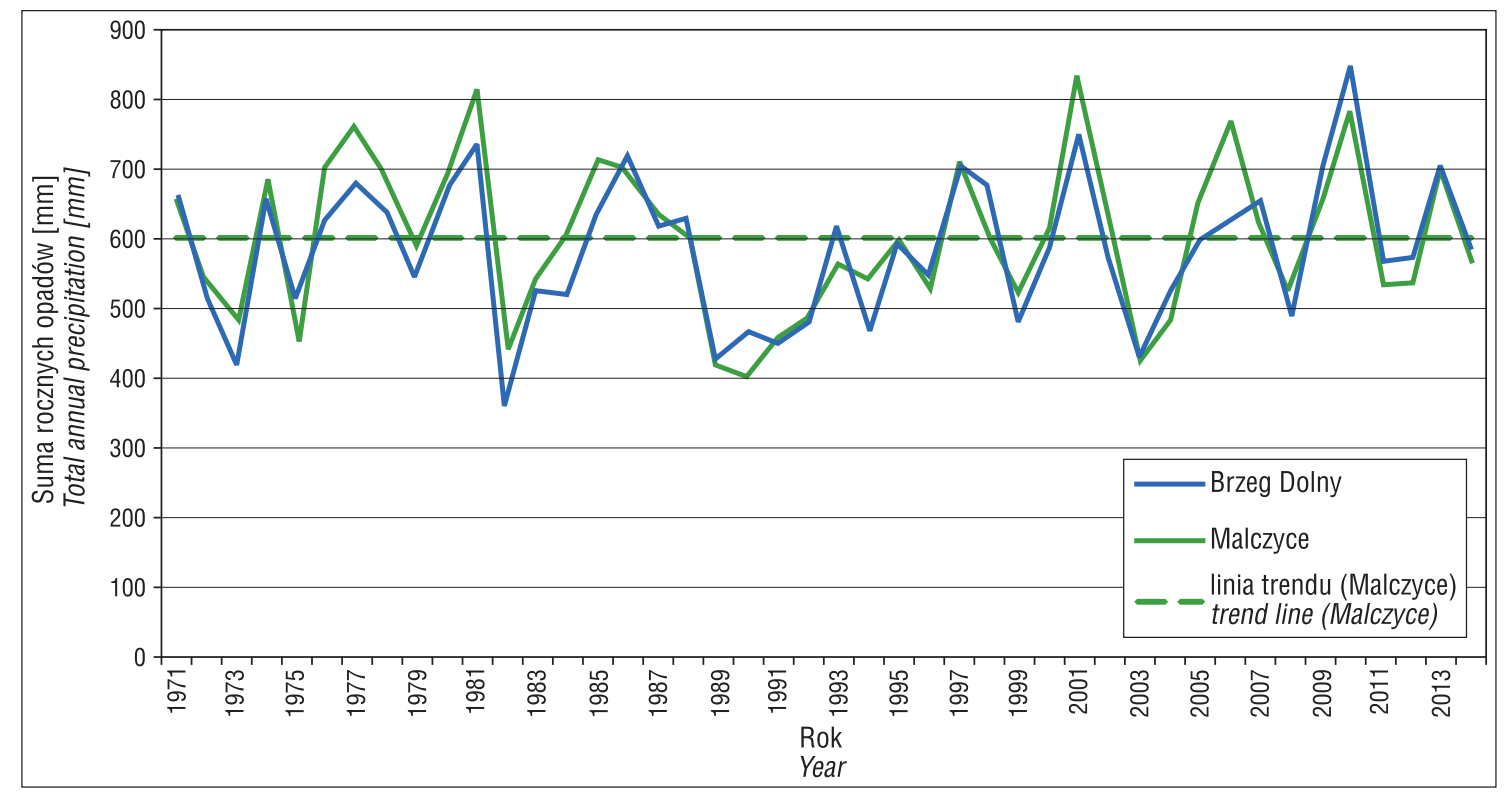

Ryc. 2. Roczne sumy opadów w latach 1971-2014 na stacjach opadowych w Brzegu Dolnym i Malczycach

Fig. 2. Precipitation in 1971-2014 in the Brzeg Dolny i Malczyce meteorological stations 
Tab. 1. Zmiany położenia zwierciadła wód podziemnych pierwszego poziomu wodonośnego pod wpływem obniżenia bazy drenażu w dolinie Odry

Table. 1. Groundwater level changes of the first aquifer due to a decreasing drainage base of the Odra Valley

\begin{tabular}{|c|c|c|c|c|c|c|}
\hline \multirow{2}{*}{$\begin{array}{l}\text { Nr punktu } \\
\text { (wg CBDH) } \\
\text { Measuring point } \\
\text { No. in CBDH }\end{array}$} & \multirow{2}{*}{$\begin{array}{c}\text { Lokalizacja } \\
\text { punktu } \\
\text { Measuring point } \\
\text { location }\end{array}$} & \multicolumn{2}{|c|}{$\begin{array}{l}\text { Rzędna zwierciadła - dane archiwalne } \\
\text { Groundwater level - archival data }\end{array}$} & \multicolumn{2}{|c|}{$\begin{array}{l}\text { Rzędna zwierciadla - pomiar wspólczesny } \\
\text { Groundwater level - current measurement }\end{array}$} & \multirow{2}{*}{$\begin{array}{c}\text { Różnica położenia } \\
\text { rzędnej zwierciadła } \\
\text { wody [m] } \\
\text { Difference in the } \\
\text { water level } \\
\text { elevations }\end{array}$} \\
\hline & & $\begin{array}{c}\text { Rzędna } \\
\text { [m n.p.m.] } \\
\text { Elevation } \\
\text { [m a.s.l.] }\end{array}$ & $\begin{array}{c}\text { Data } \\
\text { pomiaru } \\
\text { Date } \\
\text { of measurment }\end{array}$ & $\begin{array}{c}\text { Rzędna } \\
\text { [m n.p.m.] } \\
\text { Elevation } \\
\text { [m a.s.l.] }\end{array}$ & $\begin{array}{c}\text { Data } \\
\text { pomiaru } \\
\text { Date } \\
\text { of measurment }\end{array}$ & \\
\hline 7240124 & Rogów Legnicki & 96,5 & 1977 & 94,3 & IV kw. 2019 & $-2,2$ \\
\hline 7240146 & Jurcz & 94,8 & 1981 & 92,2 & IV kw. 2019 & $-2,6$ \\
\hline 6880103 & Grzybów & 93,7 & 1988 & 91,1 & IV kw. 2019 & $-2,6$ \\
\hline 6880085 & Zaborów & 92,2 & 1983 & 90,7 & I kw. 2020 & $-1,5$ \\
\hline
\end{tabular}

pierwszego poziomu wodonośnego w dolinie Odry potwierdzają również wykonane obecnie pomiary (tab. 1).

Obserwowana wielkość obniżenia poziomu wód gruntowych w powyższych punktach pomiarowych waha się w przedziale 1,5-2,6 m. Są to wartości, które znacznie przekraczają wielkość wahań sezonowych pierwszego poziomu wodonośnego. Obniżenie zwierciadła wód gruntowych jest obserwowane na całym obszarze doliny Odry na odcinku od Malczyc do Ścinawy.

Szczególnie niekorzystny wpływ obniżenia zwierciadła wód podziemnych obserwuje się na Łęgach Odrzańskich, które stanowią mozaikę zróżnicowanych siedlisk, gdzie zachowały się szczególnie cenne zbiorowiska leśne, łąkowe, szuwarowe i torfowiska niskie. Siedliska te występują $\mathrm{w}$ większości na obszarze międzywala, ale również dawnej terasy zalewowej. Ich cechą wspólną jest występowanie na terenie o wysokim poziomie wód gruntowych. $\mathrm{Na}$ skutek długotrwałego procesu obniżania się koryta Odry na odcinku od Malczyc do Ścinawy, a co za tym idzie obniżaniu się poziomu wód gruntowych w dolinie Odry, następuje dynamiczny proces przechodzenia łęgów w grądy. Zmiany położenia zwierciadła wód podziemnych są obserwowane głównie na obszarach łęgów dębowo-wiązowo-jesionowych. Szczególnie podatne na obniżenie wód gruntowych są stare dęby. Ich system korzeniowy jest wykształcony w taki sposób, że nie podąża za obniżającym się zwierciadłem wody. W ten sposób znacznie obniża się żywotność dębów, a dodatkowe czynniki takie jak grzyby czy żery owadzie (np. zwójki zieloneczki) tylko przyspieszają proces zamierania dębów.

W ostatnich latach rozważano różne sposoby sztucznego zasilania obszarów znajdujących się poniżej stopnia wodnego Malczyce (Łyczko i in., 2014). Metody polegające na sztucznym zasilaniu cieków wodnych prowadzą do lokalnego podniesienia poziomu wód gruntowych, są skuteczne, ale mają bardzo ograniczony zasięg. Z drugiej strony stopnie wodne powodują piętrzenie wód powierzchniowych powyżej budowli hydrotechnicznej. Dla projektowanych stopni wodnych w Ścinawie i Lubiążu przewidziany poziom piętrzenia statycznego wynosi odpowiednio 91,76 i 95,6 m n.p.m. Na rycinie 3 przedstawiono profil podłużny Odry na odcinku od Malczyc do Ścinawy z zaznaczanym zwierciadłem wody w rzece:

- wg danych IMGW na wodowskazach w Malczycach i Ścinawie (średnia z lat 2014-18),

- z map topograficznych z rzędną zwierciadła wody na Odrze,

- z prognozowanej rzędnej piętrzenia wody w rzece Odrze po wybudowaniu stopni wodnych w Lubiążu i Ścinawie (zgodnie ze specyfikacją istotnych warunków zamó- wienia do projektów budowlanych i projektów wykonawczych na budowę stopni wodnych).

Dane odczytane z map topograficznych można traktować jako archiwalne dane stanów wody w Odrze, chociaż bez możliwości jednoznacznego określenia datowania tych pomiarów. Na rycinie 3 wyraźnie widać różnicę pomiędzy archiwalnym stanem wody w Odrze, a średnią z pięciolecia (2014-2018). Obniżenie średnich stanów Odry na wodowskazie w Malczycach osiąga ok. 2,5 m, a na wodowskazie w Ścinawie ok. 1,0 m. Dane te potwierdzają obserwacje Parzonki i in. (2010).

$\mathrm{Na}$ rycinie 3 zaznaczono również prognozowane położenie zwierciadła wody w Odrze po wybudowaniu stopni wodnych w Lubiążu i Ścinawie. Po zrealizowaniu tych inwestycji stany wody na omawianym odcinku będą się różniły od stanu naturalnego, będą miały układ schodkowy. Należy również zauważyć, że dojdzie do podniesienia stanów wody w Odrze na znacznym odcinku. Taki stan rzeczy będzie miał wpływ na wszystkie dopływy w dolinie rzeki, jak również na położenie zwierciadła wody podziemnej pierwszego poziomu wodonośnego.

Po rozpoczęciu piętrzenia wody w Odrze, rzeka zmieni na charakter z drenującego na zasilający, do momentu wyrównania ciśnień hydrostatycznych w osadach doliny Odry. Następnie poziom piętrzenia ustanowiony przez stopnie wodne w Lubiążu i Ścinawie wyznaczą nowy poziom drenażu dla przyległego obszaru. Zasięg oddziaływania stopni wodnych Lubiąż i Ścinawa obejmie obszar doliny Odry, na którym wody podziemne pierwszego poziomu wodonośnego znajdują się obecnie poniżej poziomu projektowanej rzędnej piętrzenia statycznego wód powierzchniowych, wywołanego przez obie budowle hydrotechniczne.

W celu rozpoznania aktualnych warunków gruntowo-wodnych oraz prowadzenia pomiarów zmian położenia zwierciadła wody pierwszego poziomu wodonośnego PGW WP przewidziało wykonanie sieci obserwacyjnej, składającej się z piezometrów ujmujących pierwszy poziom wodonośny, zasadniczy z punktu widzenia oddziaływania piętrzenia na wody podziemne. Piezometry będa rozmieszczone w dolinie Odry na odcinku od wsi Małowice na północy do okolic Malczyc na południu. Zasięg oddziaływania stopni wodnych w Lubiążu i Malczycach zostanie określony na podstawie modelowania hydrogeologicznego przepływu wód podziemnych.

\section{PODSUMOWANIE I WNIOSKI}

Odra na odcinku od Brzegu Dolnego do ujścia Warty jest potocznie nazywana Odra swobodnie ptynaca. Wbrew nazwie rzeka na tym odcinku dawno straciła swój natural- 


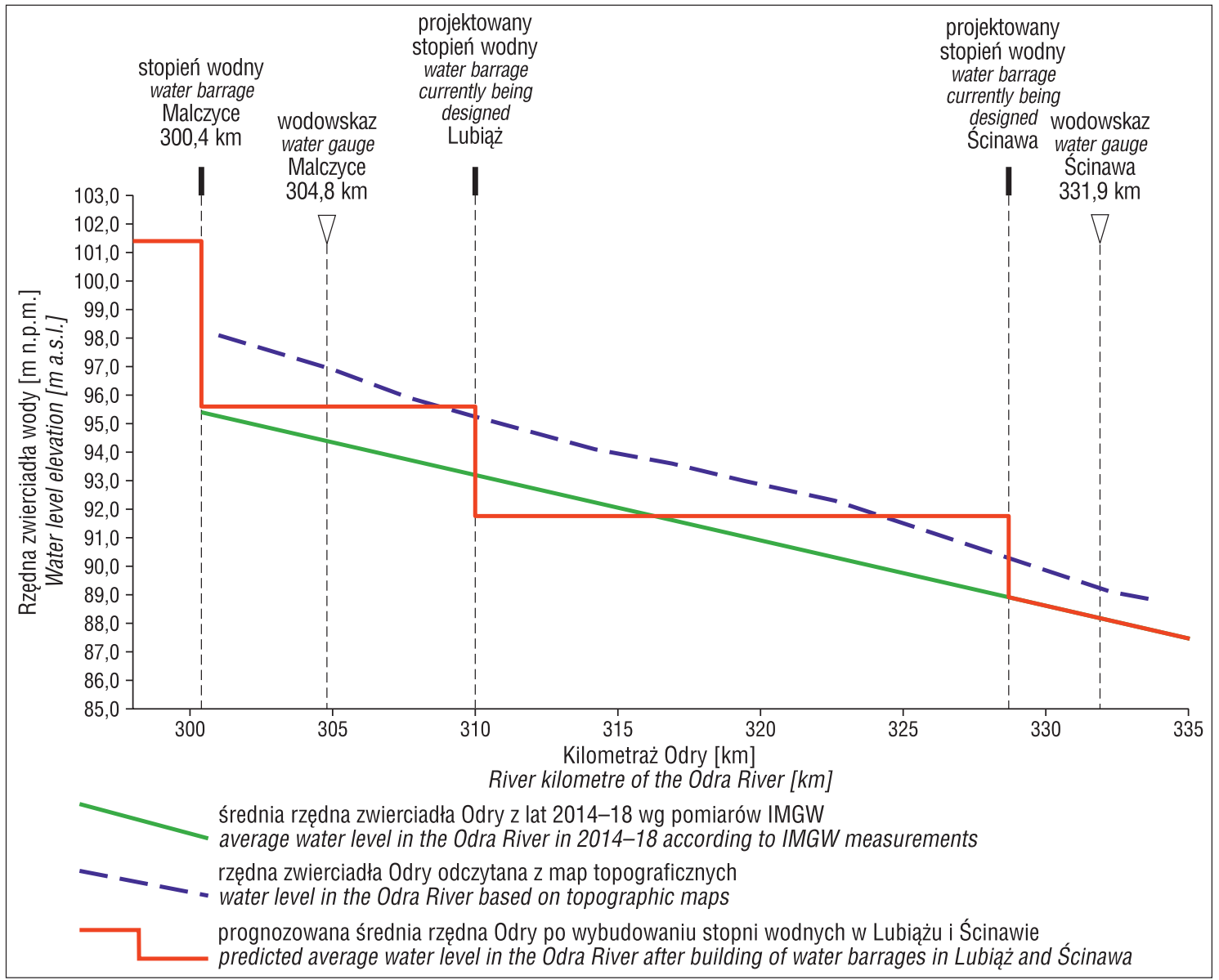

Ryc. 3. Profil podłużny Odry na odcinku od Malczyc do Ścinawy

Fig. 3. Longitudinal section of the Odra River between Malczyce and Ścinawa

ny charakter. W XIX w. przeprowadzono szereg prac regulujących nurt rzeki, wybudowano ostrogi, obwałowania. $\mathrm{Na}$ skutek budowy stopni wodnych w górnym odcinku Odry koryto rzeki stale się obniża. Skutkiem tego są niekorzystne zmiany $\mathrm{w}$ siedliskach zależnych od wysokiego poziomu wód gruntowych oraz okresowego zalewania wodami powierzchniowymi. Wybudowanie kolejnych stopni wodnych na Odrze (Lubiąż i Ścinawa) doprowadzi do dalszych znacznych zmian w reżimie wodnym rzeki na tym odcinku, jak również w wodach podziemnych obszaru doliny Odry. Najważniejsze z nich to:

- zatrzymanie erozji wgłębnej koryta Odry na odcinku od Malczyc do Ścinawy,

- podniesienie zwierciadła wód gruntowych w przyległej dolinie,

- ustabilizowanie warunków gruntowo-wodnych na znacznej powierzchni cennych przyrodniczo obszarów zależnych od wód.

Budowa stopni wodnych w Lubiążu i Ścinawie powstrzyma dalszą degradację koryta Odry i częściowo przywróci poziom zwierciadła wód podziemnych zbliżony do naturalnego.

Autorzy pragną złożyć serdeczne podziękowania Recenzentom za wartościowe i konstruktywne sugestie dotyczące prezentowanych artykule wyników badań

\section{LITERATURA}

EKSPERTYZA w zakresie rozwoju śródlądowych dróg wodnych w Polsce na lata 2016-2020 z perspektywą do roku 2030. Ministerstwo Gospodarki Morskiej i Żeglugi Śródlądowej, 2016.

GURWIN J. 2011 - Wpływ warunków środowiskowych na wody podziemne w dolinie Odry w rejonie Prochowic. Biul. Państw. Instyt. Geol., 445: $149-160$.

ŁYCZKO W., CHALFEN M., PŁYWACZYK L. 2014 - Ocena możliwości podniesienia poziomu wód gruntowych poniżej stopnia piętrzącego Malczyce. Inż. Ekolog., 39: 95-104.

MALINOWSKA-PISZ A. 1997 - Objaśnienia do Mapy Hydrogeologicznej Polski w skali 1 : 50 000, ark. Prochowice (724). Państw. Inst. Geol.

NOWICKA E., OLSZEWSKA B., PŁYWACZYK L., ŁYCZKO W. 2015 - Zmiany poziomu wód gruntowych w dolinie rzeki Odry poniżej stopnia wodnego w Brzegu Dolnym w okresie 1971-2012. Acta Sci. Pol. Formatio Circumiecutus, 14 (1): 169-178.

MICHALSKA E. 1981 - Objaśnienia do Szczegółowej Mapy Geologicznej Polski w skali 1 : 50 000, ark. Ścinawa (688). Wydaw. Geol.

PARZONKA W., KASPEREK R., GŁOWSKI R. 2010 - Ocena degradacji koryta właściwego Odry Środkowej i program działań naprawczych. Infrastruktura i Ekologia Terenów Wiejskich, 8 (1): 59-68.

RUSZLEWICZ A. 2015 - Fauna - przedmioty ochrony w obszarach Natura 2000 położonych w Krainie Łęgów Odrzańskich. Kronika Łęgów Odrzańskich nr 1. Stowarzyszenie Lokalna Grupa Działania „Kraina Łęgów Odrzańskich".

SZAŁAJDEWICZ J. 1980 - Objaśnienia do Szczegółowej Mapy Geologicznej Polski w skali 1 : 50 000, ark. Prochowice (724). Wydaw. Geol. UCHWAŁA Nr 79 Rady Ministrów z dnia 14 czerwca 2016 r. w sprawie przyjęcia ,Założeń do planów rozwoju śródlądowych dróg wodnych w Polsce na lata 2016-2020 z perspektywą do roku 2030”. M.P.2016.711 